\title{
Relevance between Transfer Pricing and Taxpayer Compliance and Marketing Accounting Management Efficiency
}

\author{
Prasetyono Hendriarto \\ Universitas Pakuan, Bogor, Indonesia
}

\begin{abstract}
Transfer pricing is crucial because every company certainly has a goal, namely to get profits through minimal expenses, perhaps reducing tax overpayments to become one of the most efficient and productive companies. To prove this hypothesis, this study has conducted a series of evidence through many special scientific publications that discuss transfer pricing of tax obligations and the accounting efficiency of corporate management. The data will certainly not be helpful and answer questions without first going through a comprehensive review process which is carried out, among others, through a phenomenological approach in which there is a critical coding and evaluation system so that we can obtain valid and detailed data to answer the last study question. Based on the data exposure supported by the evidence of field findings, we can conclude that this transfer pricing activity is indeed a part of accounting and taxation practices which allows transactions both internally within the company and with other partner companies, which of course operate in terms of 1 commitment in terms of goals and objectives. Ownership of the company and transfer pricing is also a mechanism for companies to achieve significant profits by reducing tax management rights and avoiding risk loss.
\end{abstract}

Keywords---company, efficiency, management, tax liability, transfer pricing.

\section{Introduction}

The trend of globalization is one of the essential issues in profitable business practices in modern times (Werhane et al., 2020). Because globalization allows many companies to operate in one place or country, companies can expand their existence by running and maintaining a competitive advantage wherever they start their business activities (Taylor, 2012). Businesses that want to continue to be profitable and sustainable will continue to develop ways to continue to make 
profits both in one place and in new homes. This way, the business will continue to grow, and then tax contributions to the country to increase globally will continue (Holliday, 2010). It is recognized that the growth of securities companies rather than globalization continues to grow, which not only provides economic growth for companies but also becomes world economic growth because as it is understood that the average trade of small companies in each country certainly plays a vital role in their business activities and transactions with other countries (Filippov, 2010). The transfer pricing they do can increase the number and economic growth from one place to another; on the one hand, these methods will undoubtedly benefit both parties, both the state and the company, but when practices such as the transfer of pricing (Sikka \& Willmott, 2010). All these motives and goals do not always bring prosperity to the country regarding income, but this is an unhealthy trend if practiced in company locations (Bierstaker et al., 2006).

Companies use the transfer pricing practice to determine transfer prices through transactions for goods, services, or other assets. Financial transactions carried out by this company include two models, namely fellow companies and also between companies (Filippov, 2010). One of the causes of transfer pricing is none other than if the company wants to avoid taxes, which is not allowed by state regulations. The country will get a minimal entry fee because of this action (Pratama, 2020). Instead of transfer pricing, it avoids tax obligations because this company solely aims to avoid taxes. Companies often manipulate transactions that are not following the provisions of taxpayers that have been understood by each company (Susanti \& Firmansyah, 2018). Performing transfer pricing within a company is also one of the efforts made for the smooth or efficient management of marketing accounting in a company that can sometimes operate domestically or abroad for foreign companies (Begley, 1995; Alwi et al., 2021). The government in any country needs to understand how the abuse of activities carried out by transferrin racing is carried out so that the government can fully anticipate to uncover and reduce it to reduce the impact on a country's economy (Zinn \& Riedel, 2014). Because later there will be a country that can carry on economic life without getting taxes that come from companies and business activities that occur, it is clear that companies that carry out transfer pricing are part of avoiding taxpayers and with the aim of governance efficiency-marketing accounting (Färe \& Grosskopf, 2004).

Ideally, if transfer pricing continues to occur with the motive of avoiding tax collectors, it must be recognized that the benefits of income from domestic businesses are an essential source found by the government to support a country (Sansing, 2014). So with the depletion of tax sources, it will be a severe challenge for several countries, both developed and developing countries because the rules among companies are countries that can take advantage of tax revenues so they will not suffer losses and other impacts from transfer pricing practices by companies (Lohse \& Riedel, 2013). When viewed from the motives of transfer pricing carried out by a company, for example, this is nothing but related to aspects of industrial accounting systems and practices where transfer pricing is used to maximize company profits through price regulation of goods and services by fellow companies to other companies that have the same business line (Lin \& 
Chang, 2010). Maybe according to the state so that they can say transfer pricing is fantastic.

Moreover, how to try to minimize it. First, it must be understood that God transfer pricing is a corporate scheme whose purpose is to avoid tax obligations because the taxes are so significant; this means that the state is at a loss because it tends to lose sources of tax revenue, speaking in its context. If this happens, criminal sanctions will still apply to companies that try to practice transfer pricing (Lin \& Chang, 2010). If it looks at the motive why this happened, it is none other than the existence of transactions of goods and services, automatically taxpayers will be tired of doing company internal work, so this can be minimized. There is a difference in tax rates between one company or the parent company with branch messages (Sundari \& Susanti, 2016).

Field findings prove that many domestic companies carry out transfer pricing because they avoid issuing significant taxes (Tinh, 2021; Shafiq \& Anwar, 2020). After all, material transactions are not carried out and tend not to take a compliance approach to taxpayers (Pun, 2017). Our observations are also that many variables are often used to defer taxes after the tax audit experience is carried out so that it affects the perception of transfer prices as a risk problem for many industries in managing their companies (Kustina et al., 2019). In this case, the author argues that the element of tax compliance is not optimal, so the state must take into account any data which states that the approach and transfer price, in theory, do require the government to reorganize the implementation of transfer prices-the system and the taxpayer handling system by each company (De Mooij \& Liu, 2020). Thus, this study will examine the literature from various sources more fully, which can reveal how companies that carry out transfer prices are carried out to avoid tax risk, which is an error factor. Corporate accounting governance, in which we will then summarize all the data findings and variables that influence each other, then there we will present and at the same time discuss field findings into findings that answer the problem (De Loo et al., 2011).

\section{Method}

In this section, the author tries to describe the steps in completing this review article. First, the author determines the problem and the study's title (Pathak et al., 2013). Next, search for many data from various book publication journals and website publications related to the title of this study (Umanailo et al., 2019). Further research efforts involve in-depth data analysis systems such as coding systems, high evaluations, and conclusions that answer questions relevant to the above questions and have updates (Heale \& Twycross, 2015). In determining the reporting format, we returned to the review article writing system by trying a descriptive qualitative approach based on previous findings (Heale \& Twycross, 2015). Next, we criticize whether the answers we provide are relevant to this study's questions and hypotheses. The last step is writing a draw and conclusion that we get by following a review article review report (Noble $\&$ Smith, 2015). 


\section{Discussion}

\section{Motives of transfer pricing}

Transfer prices are made for internal transactions between companies from groups of companies affiliated with each other. This happens in the industry. The decision-making effort by companies is usually the parent company, which is usually looking for profit, which means avoiding the risk of tax expenditure, which is usually a requirement of the accounting practice system of many companies in terms of marketing efficiency (Davies et al., 2018). On the other hand, the transfer pricing trend is aimed at providing added value for managers and company divisions and opening up many opportunities to achieve maximum profit, which also reduces costs. Companies in a region or country often carry out this tax by manipulating the prices of goods and services, including avoiding international taxes (Davies et al., 2018). This follows what is often used by the tax conventions of international economic cooperation and development organizations, where they often find transactions by companies that unfairly charge companies the same price. Calculate the prices regulated in the transfer pricing mechanism by economic cooperation and development organizations (Cristea \& Nguyen, 2016). So it is not surprising that many companies in countries that intentionally do transfer pricing ignores tax compliance issues when doing transfer pricing.

On the other hand, many studies raise the risk of companies in setting transfer prices influenced by the attitude of industrialized countries in companies that are not compliant with applicable laws and taxes (Sansing, 2014). So in this case, this study emphasizes the significant role of the state in complying with transfer pricing taxes for each company so that its management can control it because those investigating this problem found that the advantages of tax-compliant transfer pricing must be offset by the disadvantages of loss of flexibility and motivation for governance corporate accounting management (Spencer \& McNair, 2012). Another finding observes that many companies adjust the cost allocation system after implementing various tax compliance and transfer pricing. This situation is interesting because the perspective of risk management experienced by the company by implementing transfer pricing by avoiding tax obligations is a risk that needs to be considered by the company considering that different countries have different implementation systems, including transfer pricing and also prevent the risk of state losses on revenues (Rossing $\&$ Rohde, 2010).

\section{Impact of transfer pricing on managerial accounting}

The administrative bookkeeping system of a company, including transfer pricing, is usually carried out to overcome large expenditures, perhaps including tax costs incurred for fellow companies in the same parent company (Mura \& Emmanuel, 2010) where they usually exchange human resources for other products and services that are similar to other companies. They need each other; this is done to ease the burden of spending to make a profit, which often occurs between companies in both one country and another (Muhammadi et al., 2016). It could be in the form of human labor, and it could be goods and other equipment needed to complete the work. They seek to transfer the impact of administrative 
bookkeeping and implementation between divisional offices by encouraging alliteration and minimizing costs (Rossing \& Rohde, 2010). Cost transfers can be controlled through a cost-based, market-based strategy, or they can be managed for savings purposes.

Today, transfer pricing will usually affect the flow of communication within the company; it can be contradictory, so transfer pricing and corporate management governance are closely related (Wittendorff, 2010) so that the existence of transfer pricing will undoubtedly provide convenience for corporate management, which is essential so that companies can save money and minimize tax expenditures, which is the work done by each internal company (Satande et al., 2016; Broadbent \& Laughlin, 2009). Transfer pricing can also give strength to the managers of the company's definition to be willing to sell their goods both inside and outside the company. They consider that transfer pricing is too low where the company's definition will undoubtedly refuse to offer its goods to other divisions because of expanding the company's profits. Finally, transfer pricing is essential in selling goods and services to fellow companies even though they are between companies (Basha \& Satyasekhar, 2010).

\section{Proper transfer pricing}

The proper transfer pricing method requires a policy that determines the transfer price during transactions, both components of goods and services, or other transfers by the company (Cooper \& Sommer, 2016). Therefore transfer pricing must be a solution so that profits can be maximized, and taxpayers can also justify the transfer pricing documents themselves. Transfer pricing is a decision of the company itself in conducting transactions with other companies. Therefore, this document must be deliberately made and harmonized with taxpayer documents when conducting transactions with parties who have good relations with the company to have a fair price determination (Smith, 2015). With this principle, the company can do this by considering, for example, how the analysis and comparison determine the comparison price, for example, determining the proper method to make the correct transfer price and is followed by the principle of fairness and how the company does it.

Furthermore, knowing how to determine the proper transfer price method in a transaction that simultaneously also requires taxes and has a good relationship and most importantly, every transfer pricing has documents and steps that determine the fair price (Readhead, 2016). So that in this case, the company benefits, as well as taxes for a country following the law, can be done well. In applying the most appropriate transfer pricing, the obligation must be strong. For example, what if the advantages and disadvantages of each method must be considered and then must adjust to the transfer pricing method both at the time of the transaction and in cassation with other companies. Reliable about transfers between parties who have a good relationship (Suryarini et al., 2020).

To apply the selected method and. With the right conditions in applying this price comparison method, it is a method that has good relations between companies, for example, in transferring pricing on the prices of goods and services and also with transactions that have identical characteristics with comparable conditions 
(Johanson \& Mattsson, 2015). Alternatively, transactions made between parties who have a good relationship with the company and have accurate suitability and eliminate the influence of differences in conditions that arise following the price comparison method (Cazacu, 2017). Finally, there is also a need for a profitsharing method from the transfer pricing method, which is a method that determines transaction-based transfer prices to be carried out by identifying profits or how inter-company transactions are divided by parties who have good relations with the company as well as they have to do with profit-sharing is typically only carried out in conditions such as transactions between the parties having a good relationship (Trienekens, 2011).

Then some goods can indeed be seen between the interacting parties and cause no difficulty in finding the correct price comparison data. All governance above the need for taxes can be carried out with the condition of applying the transaction net profit method; among others, one of the parties in the transaction which has a good relationship makes a unique contribution and is ready to provide tax rights following existing laws so that it is good companies and countries both benefit from each other and benefit from each other (Cristea \& Nguyen, 2016).

\section{Transfer price impact}

Every company would want to reduce the risk of costs. Trading costs choose the costs and wages of the division itself as the executor (Hamamura, 2018). With the hope that it will reduce transaction costs that are too high, both the upstream division gets less profit, while the downstream division gets jobs and goods at a lower cost (Zhang et al., 2013). This harms assessing the introduction of the company's upstream and downstream divisions. In line with that, all upstream division parties value their works, services, and goods as if they were offering them to outside customers at very fair market prices (Martin \& Vandekerckhove, 2013). If the head of the upstream division brings decisions to the table for work and goods to outside customers and trading costs are lower than market prices, the upstream division can step down to meet internal demand and keep an eye on the untouchables. While this can bring additional benefits, it can open up opportunities for a rather lengthy goal of growing the affiliate's overall profit (Moro Visconti, 2013). Also, high trading costs can provide an exciting power for downstream divisions to oversee external suppliers, which may face the adverse impact of new breakpoints (Eden, 2012).

\section{Transfer pricing and corporate tax liability}

Transfer pricing has a significant influence in choosing the company's overall liability assessment commitment (Riedl \& Tyran, 2005). For this situation, the downstream division of the organization is in expansion with a more significant level of valuation compared to the upstream division because there is the inspiration for the overall relationship to make trade costs as high as possible (Taylor et al., 2015). This results in a lower general fee bill for all affiliates. However, there is a limit to the number of relationships across the planet that can misjudge their labor and goods for internal management purposes (Anantadjaya et al., 2021). The large body of chaotic valuation laws in different countries limits 
the ability to control moving costs (Grinenko et al., 2021). Underline. The conversion scale affects the appearance of two helpers executing each other. A too low value makes the upstream division not apply to the downstream division because it generates lower revenue. A too high value makes the downstream division not buy from the upstream because the cost is too high. Coming up at a reasonable cost helps two different organizations and enables the organization to achieve developmental benefits, enabling companies to effectively exploit largeduty measures in fulfilling taxpayers to the state (Fesenko et al., 2020).

\section{Manage taxes with transfer prices}

Transfer pricing is between seeking profit and helping to pay taxes (McGee, 2010). From the explanations above, we can say many things, for example, at the domestic and foreign company level, which relates to the transfer pricing process (Göx \& Schiller, 2006). This is a very appropriate way to respond to the problems faced by taxpayers when it comes to companies working at the international level (Bhat, 2009). This often becomes possible where the parties always hope to carry out transfer pricing to support the tax evasion model. Being a transfer pricing process, this is an emotional issue where changes often occur from time to time, which is very pragmatic if many companies carry out transfer pricing to eliminate the tax trail. This is a dangerous thing for the state (Cecchini et al., 2013). So, in this case, the theoretical framework that we have described above provides a significant contribution to how each of the above studies can provide a broad range of benefits for companies and benefits for the state as a result of Infosys transfers carried out both legally and illegally.

To increase capacity, do not lose much, assuming that the company can complete the transferring process (Behrens et al., 2014). Of course, they will get prices and can avoid spending taxes, and these methods are unhealthy by the state and provide protection, and besides, they have to bear costs due to lack of income due to transfer pricing (Krtalic \& Setic, 2013). So the essential thing is that the shift in value and taxable income is necessary for companies to overcome classic problems, which historically have been a matter that makes companies automatically have to do taxes, lay the basis for development results, which the government expects tax input from companies-operating in the territory of an independent country. By adhering to the tax obligations, companies that carry out transfer pricing should refer to policies in a country where the state protects companies, and companies also provide their income for strengthening the state so that this gives substance to the company's ever noisy roots. It follows the principles determined by the economic and development principles (Citra and Harto, 2019).

In other words, the modern taxation system is indeed fairer, so the government is indeed able to ensure that private parties and companies can pay off their rights (Mazzucato, 2011). So that here describes new progress for the state with an approach with good ways to approach and appeal to taxpayers so that they are genuinely cooperative with tax obligations (Çizakça, 2011). Therefore, they are not a company that benefits from the transfer pricing policy while the country is at a disadvantage; this is undesirable in the era of the digital economy where all parties should offer opportunities to earn profits and continue paying taxes (Core, 
2020). Moreover, this is a company that needs protection and also good governance so that there is a development and progress to obtain a match between bureaucracy and corporate ethics that needs to be considered (Cools \& Rossing, 2021). Every company that manages its company for profit and at the same time so that their company becomes sustainable and also has a positive impact on a country in terms of tax compliance so that accountants and company stability can continue to run (Arnold, 2009). Where companies' money transfer infrastructure can do professional things, then taxes will be fulfilled, and companies will make ties and operational efficiency (Martono et al., 2020).

\section{Conclusion}

The final section of this study will conclude the essential points of the study entitled the relevance of transfer pricing and zinc complaints and the efficiency of accounting management in corporate marketing. We believe that this finding has fulfilled the elements of data quality and accountability were; with this report, we have conducted a series of electronic data searches that we focus on how to obtain dividends from field studies that can prove that there is a correlation between transfer pricing of tax obligations and efficiency. Within the company. Conclusion We are answered that there is a correlation or relevance between transfer pricing and tax liability and the efficiency of the company's accounting management. Among other things, we explain the real motive of transferring praising by companies in operating their feelings to make a profit through practices that allow less expenditure but more profit. This is already the principle of every company regardless of practices that may not be compatible with laws and ethical policies by country, but this is a trend in corporate governance. In another section, we also explain how the impact of transfer pricing on the effectiveness of accounting and management, where every company certainly makes every choice they make with the consideration of effectiveness in terms of profit and sustainability.

Another time that we describe is, for example, how an excellent transfer pricing means giving benefits to the company and also providing benefits in the form of taxes to the state so that this company is indeed an effective company towards profit and also buys bags and is ethical in carrying out their duties and activities. The following points that we note include the impact of transfer pricing on costs and personal safety for companies to ensure that they have performed their obligations in terms of work and obligations. The next is transfer pricing, and compliance with taxes as We all know that for the sake of company efficiency and big profits, companies often ignore legal obligations and obey the regulations that apply, especially in terms of paying taxes. The next point is how tax governance and transfer pricing are correct, allowing the benefit of many parties, both from the company itself to employees and informants. Effectiveness is also to the managerial accountants of the company who do not ignore the rights and responsibilities so that this company has implemented ethics and corporate models that are sufficient for sticking rather than developing. 


\section{Acknowledgments}

Here the author sends thousands of thanks for all campus support and financial support from the ministry of education of the Republic of Indonesia. We believe that without the help and attention of all of this, we certainly could not carry out this task better than expected.

\section{References}

Alwi, M. A. bin M., Abdullah, A. bin, \& Luqman, A. binti. (2021). Debt management literacy among credit cards users. Linguistics and Culture Review, 6(S1). https://doi.org/ 10.21744/lingcure.v6nS1.1897

Anantadjaya, S. P., Nawangwulan, I. M., Irhamsyah, M., \& Carmelita, P. W. (2021). Supply chain management, inventory management \& financial performance: evidence from manufacturing firms. Linguistics and Culture Review, 5(S1), 781-794. https://doi.org/10.21744/lingcure.v5nS1.1463

Arnold, P. J. (2009). Global financial crisis: The challenge to accounting research. Accounting, organizations and Society, 34(6-7), 803-809. https://doi.org/10.1016/j.aos.2009.04.004

Basha, A. N., \& Satyasekhar, G. V. (2010). Modus operandi of transnational transfer pricing for window dressing. Journal of Modern Accounting and Auditing, 6(6), 51.

Begley, T. M. (1995). Using founder status, age of firm, and company growth rate as the basis for distinguishing entrepreneurs from managers of smaller businesses. Journal of business venturing, 10(3), 249-263. https://doi.org/10.1016/0883-9026(94)00023-N

Behrens, K., Peralt, S., \& Picard, P. M. (2014). Transfer pricing rules, OECD guidelines, and market distortions. Journal of Public Economic Theory, 16(4), 650-680.

Bhat, G. (2009). Transfer pricing, tax havens and global governance (No. 7/2009). Discussion Paper.

Bierstaker, J. L., Brody, R. G., \& Pacini, C. (2006). Accountants' perceptions regarding fraud detection and prevention methods. Managerial Auditing Journal.

Broadbent, J., \& Laughlin, R. (2009). Performance management systems: A conceptual model. Management Accounting Research, 20(4), 283-295. https:/ / doi.org/10.1016/j.mar.2009.07.004

Cazacu, A. L. (2017). Transfer Prices And Market Value Of Reinsurance Transactions. Annals of the University of Craiova, Economic Sciences Series, 1(45).

Cecchini, M., Leitch, R., \& Strobel, C. (2013). Multinational transfer pricing: A transaction cost and resource based view. Journal of Accounting Literature, 31(1), 31-48. https://doi.org/10.1016/j.acclit.2013.06.001

Citra, V. T., \& Harto, P. (2019). Transfer Pricing Aggressiveness, Firm Size, Profitability, And Tax Haven Utilization As Determinants of Tax Avoidance Empirical Evidence from Companies Listed in Indonesia (Doctoral dissertation, Fakultas Ekonomika dan Bisnis).

Çizakça, M. (2011). Islamic capitalism and finance: Origins, evolution and the future. Edward Elgar Publishing. 
Cools, M., \& Rossing, J. (2021). International Transfer Pricing: MNE Dependency on Knowledge of External Tax ConsultantsMNE Dependency on Knowledge of External Tax Consultants. Journal of Management Accounting Research.

Cooper, R. G., \& Sommer, A. F. (2016). The agile-stage-gate hybrid model: a promising new approach and a new research opportunity. Journal of Product Innovation Management, 33(5), 513-526.

Core, E. (2020). Value creation in the beps era and a new approach to transfer pricing for intangibles.

Cristea, A. D., \& Nguyen, D. X. (2016). Transfer pricing by multinational firms: New evidence from foreign firm ownerships. American Economic Journal: Economic Policy, 8(3), 170-202.

Davies, R. B., Martin, J., Parenti, M., \& Toubal, F. (2018). Knocking on tax haven's door: Multinational firms and transfer pricing. Review of Economics and Statistics, 100(1), 120-134.

De Loo, I., Verstegen, B., \& Swagerman, D. (2011). Understanding the roles of management accountants. European Business Review.

De Mooij, R., \& Liu, L. (2020). At a cost: The real effects of transfer pricing regulations. IMF Economic Review, 68(1), 268-306.

Eden, L. (2012). Transfer price manipulation. Draining Development: Controlling Flows of Mlicit Funds from Developing Countries, Washington DC: World Bank.

Färe, R., \& Grosskopf, S. (2004). Modeling undesirable factors in efficiency evaluation: comment. European Journal of Operational Research, 157(1), 242245. https:/ / doi.org/10.1016/S0377-2217(03)00191-7

Fesenko, V., Vakulchyk, O., Guba, O., Ostapchuk, S., \& Babich, I. (2020). The results of implementation of european requirements in management of transfer pricing audit (experience of Ukraine). Independent Journal of Management \& Production, 11 (9), 2417-2434.

Filippov, S. (2010). Russian companies: the rise of new multinationals. International Journal of Emerging Markets.

Göx, R. F., \& Schiller, U. (2006). An economic perspective on transfer pricing. Handbooks of management accounting research, 2, 673-695. https://doi.org/10.1016/S1751-3243(06)02009-8

Grinenko, J., Melnychuk, D., Mykhalchyshyna, L., Belei, S., \& Yevtushenko, N. (2021). Improving transfer pricing in Ukraine using American Experience. Independent Journal of Management \& Production, 12(3), s205s231.

Hamamura, J. (2018). The impact of an information linkage system on a firm's organization structure, transfer price, and profit. Asia-Pacific Management Accounting Journal, 13(1), 131-152.

Heale, R., \& Twycross, A. (2015). Validity and reliability in quantitative studies. Evidence-based nursing, 18(3), 66-67.

Holliday, A. (2010). Analysing qualitative data. Continuum companion to research methods in applied linguistics, 98-110.

Johanson, J., \& Mattsson, L. G. (2015). Internationalisation in industrial systems-a network approach. In Knowledge, networks and power (pp. 111132). Palgrave Macmillan, London.

Krtalic, S., \& Setic, E. (2013). Tax implications of using transfer pricing. Economic and Social Development: Book of Proceedings, 443.

Kustina, K.T., Dewi, G.A.A.O., Prena, G.D., Suryasa, W. (2019). Branchless banking, third-party funds, and profitability evidence reference to banking 
sector in indonesia. Journal of Advanced Research in Dynamical and Control Systems, 11(2), 290-299.

Lin, C. W., \& Chang, H. C. (2010). Motives of transfer pricing strategies-systemic analysis. Industrial Management \& Data Systems.

Lohse, T., \& Riedel, N. (2013). Do transfer pricing laws limit international income shifting? Evidence from European multinationals.

Martin, S., \& Vandekerckhove, J. (2013). Market performance implications of the transfer price rule. Southern economic journal, 80(2), 466-487.

Martono, S., Yulianto, A., Witiastuti, R. S., \& Wijaya, A. P. (2020). The role of institutional ownership and industry characteristics on the propensity to pay dividend: An insight from company open innovation. Journal of Open Innovation: Technology, Market, and Complexity, 6(3), 74.

Mazzucato, M. (2011). The entrepreneurial state. Soundings, 49(49), 131-142.

McGee, R. W. (2010). Ethical issues in transfer pricing. Manchester J. Int'l Econ. L., $7,24$.

Moro Visconti, R. (2013). Evaluating know-how for transfer price benchmarking. Journal of Finance and Accounting, 1(1), 27-38.

Muhammadi, A. H., Ahmed, Z., \& Habib, A. (2016). Multinational transfer pricing of intangible assets: Indonesian tax auditors' perspectives. Asian Review of Accounting.

Mura, A., \& Emmanuel, C. (2010). Transfer pricing: early Italian contributions. Accounting, Business \& Financial History, 20(3), 365-383.

Noble, H., \& Smith, J. (2015). Issues of validity and reliability in qualitative research. Evidence-based nursing, 18(2), 34-35.

Pathak, V., Jena, B., \& Kalra, S. (2013). Qualitative research. Perspectives in clinical research, 4(3).

Pratama, A. (2020). Corporate governance, foreign operations and transfer pricing practice: the case of Indonesian manufacturing companies. International Journal of Business and Globalisation, 24(2), 185-200.

Pun, G. (2017). Base erosion and profit shifting: How corporations use transfer pricing to avoid taxation. BC Int'l \& Comp. L. Rev., 40, 287.

Readhead, A. (2016). Transfer pricing in the mining sector in Zambia. Case Study, Natural Resources Governance Institute, https://resourcegovernance. org/sites/default/files/documents/nrgi_zambia_transfer-pricingstudy. pdf.

Riedl, A., \& Tyran, J. R. (2005). Tax liability side equivalence in gift-exchange labor markets. Journal of public Economics, 89(11-12), 2369-2382. https://doi.org/10.1016/j.jpubeco.2004.08.007

Rossing, C. P., \& Rohde, C. (2010). Overhead cost allocation changes in a transfer pricing tax compliant multinational enterprise. Management Accounting Research, 21(3), 199-216. https://doi.org/10.1016/j.mar.2010.01.002

Sansing, R. (2014). International transfer pricing. Foundations and Trends ${ }^{\circledR}$ in Accounting, 9(1), 1-57.

Satande, J. T., Hove, U., \& Jachi, M. Taxation Policy and Tax Administration Efficiency: Evidence from Zimbabwe's Transfer Pricing Legislation of 2016.

Shafiq, S., \& Anwar, N. (2020). Raees as Macbeth-A transcultural adaptation. International Journal of Linguistics, Literature and Culture, 6(4), 6-15. https://doi.org/10.21744/ijllc.v6n4.901

Sikka, P., \& Willmott, H. (2010). The dark side of transfer pricing: Its role in tax avoidance and wealth retentiveness. Critical Perspectives on Accounting, 21(4), 342-356. https://doi.org/10.1016/j.cpa.2010.02.004 
Smith, A. O. (2015). The Impact of Transfer Pricing on Financial Reporting: A Nigerian Study. Research Journal of Finance and Accounting, 6(16).

Spencer, D., \& McNair, D. (2012). Transfer pricing: Will the OECD adjust to reality. Journal of International Taxation, 23, 34-52.

Sundari, B., \& Susanti, Y. (2016). Transfer pricing practices: empirical evidence from manufacturing companies in Indonesia. Asia-Pacific Management Accounting Journal, 11(2), 25-39.

Suryarini, T., Cahyaningrum, A. M., \& Hidayah, R. (2020). The Effect of Tunneling Incentive to Transfer Pricing Decision with Tax Minimization As a Moderating Variable. KnE Social Sciences, 1-13.

Susanti, A., \& Firmansyah, A. (2018). Determinants of transfer pricing decisions in Indonesia manufacturing companies. Jurnal Akuntansi dan Auditing Indonesia, 22(2), 81-93.

Taylor, G., Richardson, G., \& Lanis, R. (2015). Multinationality, tax havens, intangible assets, and transfer pricing aggressiveness: An empirical analysis. Journal of International Accounting Research, 14(1), 25-57.

Taylor, S. D. (2012). Globalization and the Cultures of Business in Africa: from patrimonialism to profit. Indiana University Press.

Tinh, T. T. (2021). Research on autonomy and accountability of high schools in Vietnam. International Journal of Linguistics, Literature and Culture, 7(6), 459-467. https://doi.org/10.21744/ijllc.v7n6.1946

Trienekens, J. H. (2011). Agricultural value chains in developing countries; a framework for analysis. International food and agribusiness management review, 14(2), 51-83.

Umanailo, M. C. B., Hamid, I., Hamiru, H., Assagaf, S. S. F., Bula, M., Nawawi, M., ... \& Bon, A. T. (2019). Utilization of Qualitative Methods in Research Universities. Education science, 21, 2076-2081.

Werhane, P. H., Wolfe, R. W., \& Newton, L. H. (2020). Alleviating poverty through profitable partnerships: Globalization, markets, and economic well-being. Routledge.

Wittendorff, J. (2010). Transfer pricing and the arm's length principle in international tax law (Vol. 35). Kluwer Law International BV.

Zhang, D., Samsatli, N. J., Hawkes, A. D., Brett, D. J., Shah, N., \& Papageorgiou, L. G. (2013). Fair electricity transfer price and unit capacity selection for microgrids. Energy Economics, 36, 581-593. https://doi.org/10.1016/j.eneco.2012.11.005

Zinn, T., \& Riedel, N. (2014). The increasing importance of transfer pricing regulations: a worldwide overview. Intertax, 42(6/7). 